\title{
A new method to determine open porosity and permeability constants of open- pore sintered glasses by photoacoustic technique
}

\section{(Um novo método para determinar a porosidade e as constantes de permeabilidade de filtros vitreos por meio da técnica fotoacústica)}

\author{
M. T. Yasuda ${ }^{\text {, W. L. B. Melo }}{ }^{2}$ \\ ${ }^{1}$ Departamento de Engenharia de Materiais - DEMa \\ Universidade Federal de S. Carlos - UFSCar \\ Rod. Washington Luiz, km 235, C.P. 676, S. Carlos, SP 13.565-905 \\ ${ }^{2}$ Embrapa Instrumentação Agropecuária \\ Rua XV de Novembro 1452, C.P. 741, S. Carlos, SP 13.560-970 \\ mtyasuda@cnpdia.embapa.br,wlbmelo.cnpdia.embrapa.br
}

\begin{abstract}
The Photoacoustic (PA) technique was used to investigate the structural properties (e.g. open porosity and permeability) of open-pore sintered glasses. This work demonstrates that the photoacoustic signal of open-pore sintered glasses, which are produced with different grain sizes and several degrees of open porosity, is sensitive to the morphology of the open-pore samples. The results obtained by the PA technique were related to results obtained by the Pressure Decay technique, and an excellent correlation was obtained. This demonstrates that PA technique, which is non-intrusive and non-destructive, is promising for application in analysis of porous ceramic structures, even if the sample is semi-transparent.
\end{abstract}

Keywords: open porous, permeability, glasses, photoacoustic.

\section{Resumo}

A técnica fotoacústica (PA) foi usada para investigar as propriedades estruturais (isto é, porosidade aberta e permeabilidade) de filtros vitreos. Este trabalho demonstra que o sinal fotoacústico de filtros vítreos, os quais foram produzidos com diferentes tamanhos de grãos e vários graus de porosidade, é sensível à morfologia destes. Os resultados obtidos pela técnica PA foram relacionados com resultados de permeabilidade obtidos pela técnica de decaimento de pressão, resultando em uma ótima correlação. Isto demonstra que a técnica fotoacústica, a qual é não intrusiva e não destrutiva, é promissora para análise de estruturas cerâmicas porosas, mesmo sendo essas semi-transparentes.

Palavras-chave: porosidade aberta, permeabilidade, vidros, fotoacústica.

\section{INTRODUCTION}

Open-pore sintered soda lime glasses are important in filtration and purification systems, being used due to their stability and chemical resistance [1]. In order to apply these materials effectively, knowledge of the quantity of openpores as well as the permeability is very important because of their influence on the filtration efficiency. In this light, an alternative, non-invasive and non-destructive method, which is based on the photoacoustic (PA) technique, is proposed in order to investigate the open-pore morphology. Despite the fact that the PA technique was first discovered more than one century ago (A. G. Bell in 1880 [2]), its use in research has only received considerable attention since the 70's [2-7]. In the PA technique the sample is placed inside a closed cell (PA cell) that contains air and a sensitive microphone. The sample is then illuminated with chopped polychromatic or monochromatic light. The incident light 
may be scattered, transmitted and/or absorbed depending on the optic absorption coefficient and structure of the sample. The modulated light absorbed by the sample excites energy levels that subsequently decay. The most common decay process is non-radioactive decay (heating), and thus the periodic optical excitation of the sample results in a periodic flow of heat from the sample to the surrounding air $[2,8]$. This propagation results in a periodic pressure oscillation within the PA cell, which is detected by the microphone as an acoustic signal (PA signal). The transmitted light can also be used to indirectly produce the PA signal, as will be demonstrated in this paper.

The PA signal depends on the thermal and optical properties of the sample and consequently also depends on the structure of the sample. In the 1970's theoretical models were formulated which considered these contributions [2, 8, 9-11]. In the 1980 's, studies with powdered and porous samples were performed, leading to the formulation of a theoretical model by Monchalin. [12]

\section{EXPERIMENTAL PROCEDURE}

Open-Pore Sintered Glass. Open-pore sintered soda lime glasses were prepared using the simplest manufacturing process in order to achieve open-pore vitreous bodies with reasonably defined pore-size ranges. This is called the Filler Principle and was introduced by Sibers [14]. In this process a non-sinterable and a water-soluble phase $(\mathrm{NaCl})$ were added to the glass grains at percentages of 0, 10, 20, 30 and 40 wt.\%. The glass grains were obtained from a transparent bottle obtained commercially and had the following chemical composition (in mol \%): $\mathrm{SiO}_{2}$ (72.8\%), $\mathrm{Na}_{2} \mathrm{O}$ (13.2 \%), $\mathrm{CaO}$ (11.2\%), $\mathrm{Al}_{2} \mathrm{O}_{3}$ (2.13\%), $\mathrm{MgO}(0.16 \%), \mathrm{K}_{2} \mathrm{O}$ (0.09\%), $\mathrm{Fe}_{2} \mathrm{O}_{3}(0.039 \%)$ and $\mathrm{FeO}(0.039 \%)$ [15]. Two different

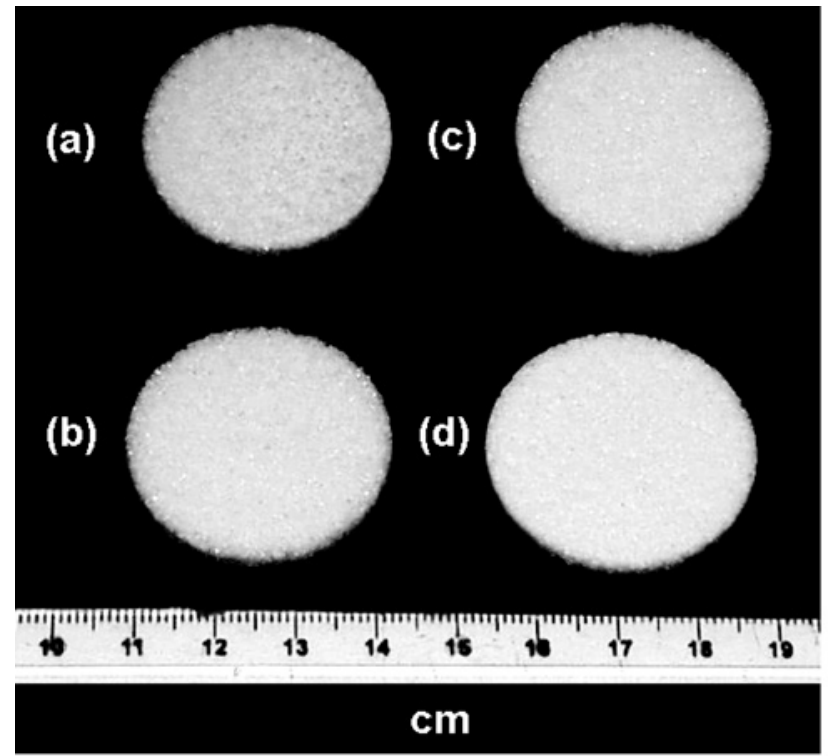

Figure 1: Photograph of some samples, with different open porosity, used in this work: $15.04 \%$ of open porosity (produced with grains between $106 \mu \mathrm{m}$ and $212 \mu \mathrm{m}$ ); $28.69 \%$ of open porosity (produced with grains between $212 \mu \mathrm{m}$ and $500 \mu \mathrm{m}$ ); 40.74\% of open porosity (produced with grains between $106 \mu \mathrm{m}$ and $212 \mu \mathrm{m}$ ); $51.64 \%$ of open porosity (produced with grains between $212 \mu \mathrm{m}$ and $500 \mu \mathrm{m})$.

[Figura 1: Fotografia de algumas amostras, com diferentes porosidades abertas, utilizadas no trabalho: $15,04 \%$ de porosidade aberta (produzidas com grãos entre $106 \mu \mathrm{m}$ e $212 \mu \mathrm{m}$ ); 28,69\% de porosidade aberta (produzidas com grãos entre $212 \mu \mathrm{m}$ e $500 \mu \mathrm{m}$ ); $40,74 \%$ de porosidade aberta (produzidas com grãos entre $106 \mu \mathrm{m}$ e $212 \mu \mathrm{m}$ ); 51,64\% de porosidade aberta (produzidas com grãos entre $212 \mu \mathrm{m}$ e $500 \mu \mathrm{m})$.]

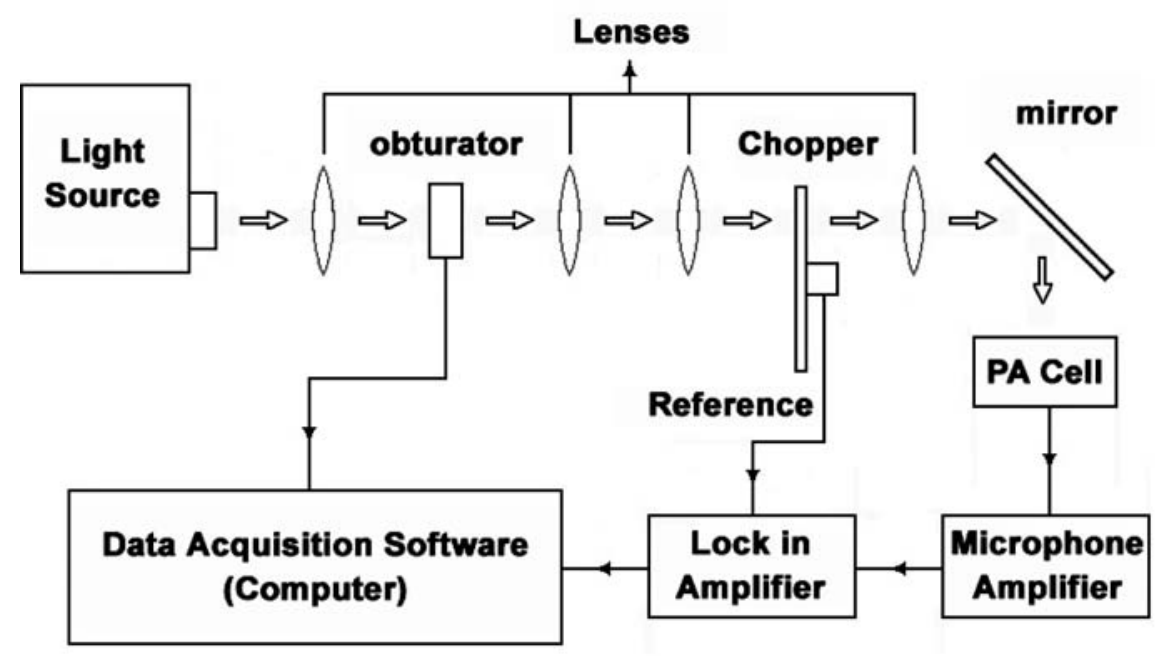

Figure 2: Schematic representation of the PA spectrometer.

[Figure 2: Representação esquemática do espectrômetro PA.] 
glass grain sizes were used, one with grains between 106 $\mu \mathrm{m}$ and $212 \mu \mathrm{m}$ and other between $212 \mu \mathrm{m}$ and $500 \mu \mathrm{m}$. The samples were sintered at a temperature of $700^{\circ} \mathrm{C}$ for 60 min. After being washed, the thickness of the samples was standardized at $4 \mathrm{~mm}$. The samples were approximately 35 $\mathrm{mm}$ in diameter. Fig. 1 shows some samples manufactured by the method described above [10].

PA Instrumentation. The experiment was realized in a photoacoustic spectrometer assembled in the Photothermal Laboratory of the Embrapa Instrumentation Research Center. This spectrometer consists of a halogen lamp (Oriel, $250 \mathrm{~W}$ ), a chopper (Oriel, 75152), a microphone (B\&Kmodel 4192) with preamplifier and conditioning amplifier (B\&K-Nexus), an amplifier Lock-in (Stanford-SR530) and data acquisition software. A schematic diagram of the PA spectrometer is presented in Fig. 2.

The PA cell used was constructed with a special sample holder. Two identical aluminum holders were made and one was covered with a thin layer of black ink (black holder $\mathrm{BH}$ ) and the other remained with its natural color (white holder - WH).

Methodology. The proposed method used in this paper consists of obtaining the different PA signals related to the open pore structure of the samples using the two different holders, as a function of modulation frequency of the light beam. The PA signal of the sample present in the WH depends on the light absorption and scattering on its surface, and also on the light reflected by the WH that can be reabsorbed by the sample. The PA signal of sample on the $\mathrm{BH}$ depends predominantly on the light transmitted through the sample and absorbed by the support. This absorption by the support increases the PA signal in relation to that obtained using the WH. Also a difference in the behavior of the signal, as the modulation frequency is changed, is observed.

In the interface between the sample and the sample holder a thin layer of air is present due to the roughness and open pores of the sample surface. When the $\mathrm{BH}$ is used, acoustic waves are generated in this layer of air by the thermal waves that originate from the $\mathrm{BH}$. These thermal-acoustic waves spread through the sample generating the expansion of the interstitial air and contribute to the increase of the PA signal. These effects mainly depend on the sample structure and its permeability.

Information concerning the structure of the open pores can be obtained by relating the amplitude of the PA signals that are obtained for samples using the different supports. Equation A describes this relationship:

$$
\frac{R}{m}=\frac{(P A \text { signal amplitude of sample })_{B H}}{m(P A \text { signal amplitude of sample })_{W H}}
$$

where $R$ is the normalized amplitude of the PA signal and $m$ is the mass of sample. $R / m$ represents the contribution of the open pore structure to the propagation of the thermo-acoustic waves through the sample, while the other contributions (surrounding conditions, light power, absorption coefficient, etc.) are minimized.

\section{RESULTS AND DISCUSSION}

Fig. 3 shows the behavior of $R / m$, for both sample groups, as a function of the frequency modulation of the incident light-beam. It should be noted that $R / m$ increases with the open pore percentage. This behavior is similar for both groups of samples with different grain sized intervals;

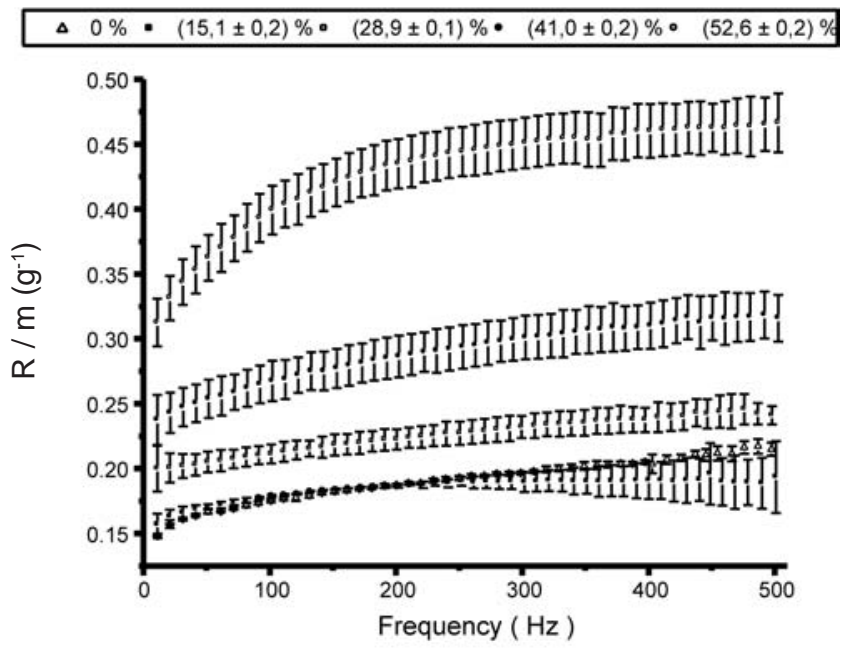

(a)

$\Delta \quad 0 \% \cdot(14,54 \pm 0,04) \% \cdot(28,35 \pm 0,06) \% \cdot(40,7 \pm 0,4) \% \bullet \quad(52 \pm 1) \%$

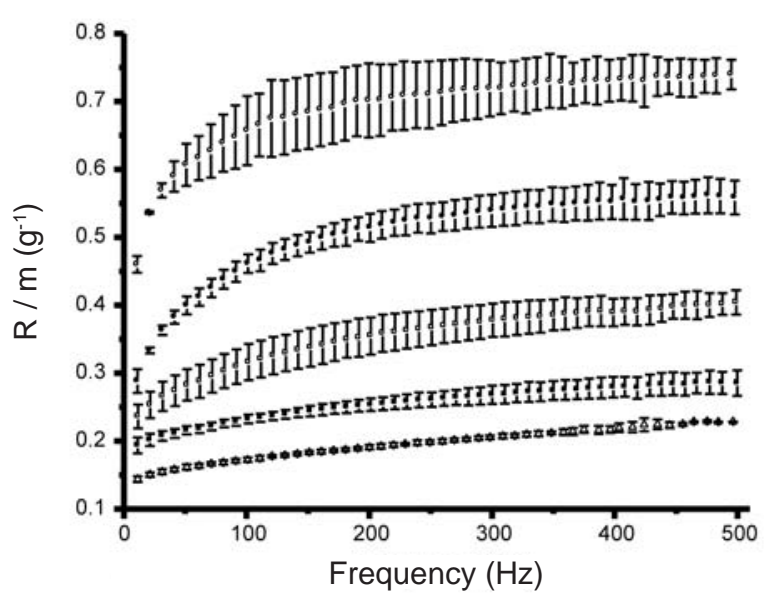

(b)

Figure 3: Behavior of $R / m$ for samples with grain sizes between: (a) $106 \mu \mathrm{m}$ and $212 \mu \mathrm{m}$, (b) $212 \mu \mathrm{m}$ and $500 \mu \mathrm{m}$. The captions above the figures present the open porosity of the sample groups. [Figura 3: Comportamento de $R / m$ para amostras com tamanho de grãos entre (a) $106 \mu \mathrm{m}$ e $212 \mu \mathrm{m}$, (b) $212 \mu \mathrm{m}$ e $500 \mu \mathrm{m}$. As legendas acima dos gráficos apresentam as porosidades aberta dos grupos de amostras.] 
however, the group formed by bigger grains evolves more uniformly.

Note that $R / m$ increases with the frequency and tends to a constant value. At low frequencies the thermal diffusion length of air is greater than at high frequencies and this can be used to explain the behavior of $R / m$ in Fig. 3. When the thermal diffusion length of air is greater than the air gap in the layer between the sample and $\mathrm{BH}$, the contribution to the expansion of interstitial air is due to thermal waves. However, when the thermal diffusion length of air is smaller than the air gap, the acoustic waves are generated and propagate through the sample and by interstitial air.

The PA technique is a nondestructive technique. Thus, in order to provide a comparative study the same samples were also analyzed by the Pressure Decay technique. The experimental apparatus used was that constructed by Vasques et al. [16] Thus, using the Forchheimer equation (equation B) for a compressible fluid (air) $[16,17]$, the Darcian $\left(k_{1}\right)$ and non-Darcian $\left(k_{2}\right)$ permeability constants were obtained according to:

$$
\frac{P_{e}{ }^{2}-P_{e x}{ }^{2}}{2 P_{0} L_{s}}=\frac{v}{k_{1}} v_{s}+\frac{\rho_{f}}{k_{2}} v_{s}{ }^{2}
$$

where $P_{e}$ and $P_{e x}$ are the entrance and exit pressures from sample, respectively; $P_{0}$ is the atmospheric pressure; $L_{s}$ is the sample thickness; $v$ is the fluid viscosity $\left(1,83 \times 10^{-5} \mathrm{~Pa} . s\right) ; v_{s}$ is the fluid velocity; and $\rho_{f}$ is the fluid density $\left(1,079 \mathrm{Kg} / \mathrm{m}^{3}\right)$ [16].

The pressure-decay curves as a function of fluid velocity of the samples (fitted using equation B) are presented in Fig. 4. The curves demonstrate that the increase in the pressure decay is greater as the fluid velocity increases and the open porosity of the sample is reduced. In figure $4 \mathrm{a}$ the curve of the sample with $15.04 \%$ open porosity is not presented because it did not present a fluid flux through the sample. This suggests that these samples do not have interconnected pores linking the surface, as commented previously.

The Darcian permeability constant $\left(k_{1}\right)$ is related to the viscous attrition between the fluid and the porous structure and the molecules of the fluid. The non-Darcian permeability constant $\left(k_{2}\right)$ is related to the effect of fluid turbulence through the open structure on the pressure decay $[17,18]$. The viscous attrition effect predominates at low fluid velocities and contributes to the evolution of $R / m$ in a similar manner for both sample groups. In other words, $R / m$ is not sufficiently sensible to distinguish this effect for different sample groups, as shown in figure 5a.

The effect of the fluid turbulence on the pressure decay depends predominantly on high fluid velocities and also depends on the waviness of the interconnected open pores $[17,18]$. In this case, $R / m$ distinguishes the different sample groups and figure $5 \mathrm{~b}$ demonstrates this fact. This difference is possibly due to periodical expansion of the interstitial air which occurs in the sound velocity region, so that it is possible

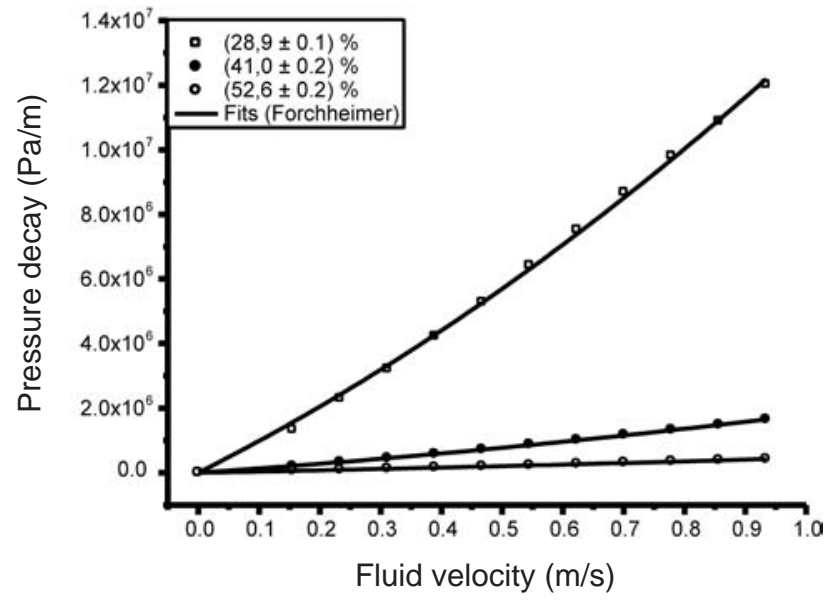

(a)

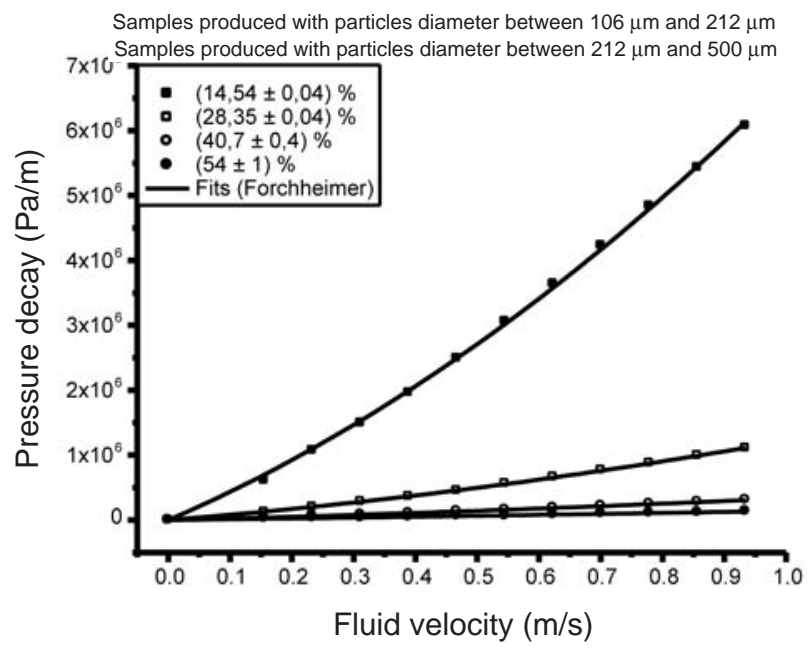

Figure 4: Pressure decay as a function of fluid velocity for samples produced with grain sizes between: a) $106 \mu \mathrm{m}$ and $212 \mu \mathrm{m}$, (b) 212 $\mu \mathrm{m}$ and $500 \mu \mathrm{m}$.

[Figura 4: Decaimento de pressão em função da velocidade do fluido para amostras produzidas com tamanhos de grãos entre: a) $106 \mu \mathrm{m}$ e $212 \mu \mathrm{m}$, (b) $212 \mu \mathrm{m}$ e $500 \mu \mathrm{m}$.]

to compare the difference between the samples manufactured with different grain sizes in relation to the possible structural differences formed by interconnected open pores.

The fittings presented in Fig. 5 were obtained using an exponential function that relates $R / m$ to the permeability constants. The equation used for fitting is:

$$
\frac{R}{m}=C_{0}\left(1+C_{j}^{(i)} e^{\alpha_{i}^{(i)} k_{j}}\right)
$$

where $C_{0}$ is a constant related to the impermeable sample, $C_{j}^{(i)}$ and $\alpha^{(i)}{ }_{j}$ are parameters that depend on the sample 


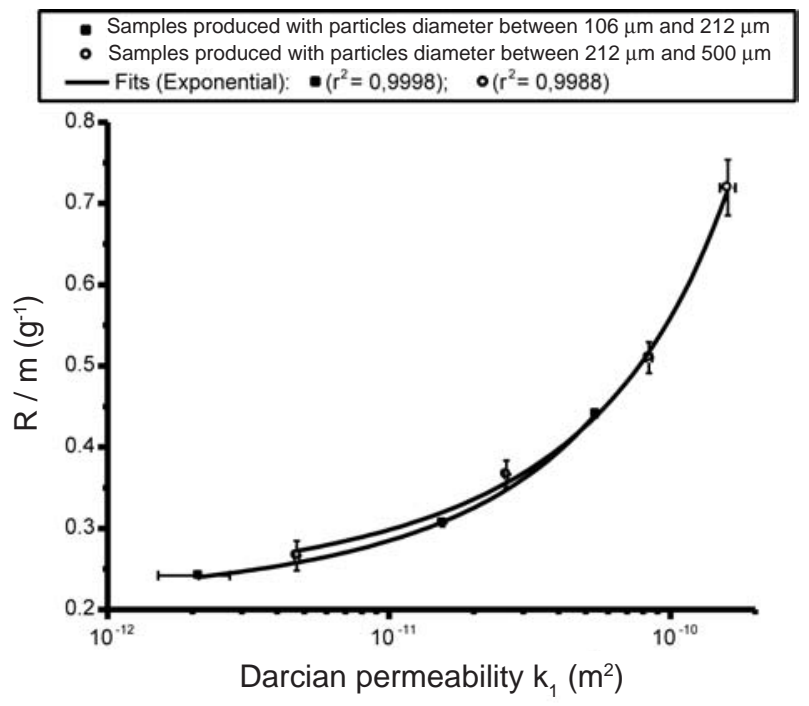

(a)

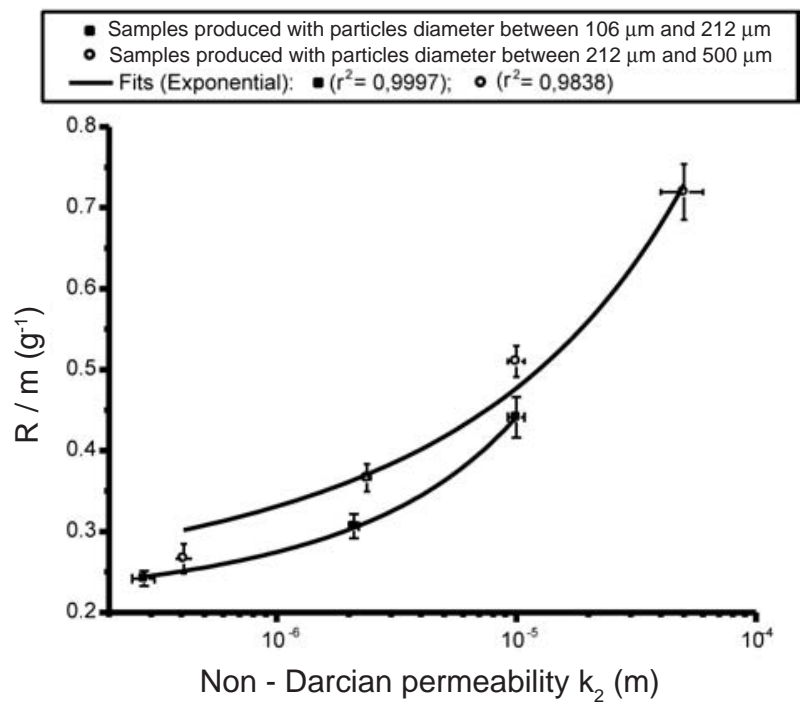

b)

Figure 5: Correlation between $R / m$ and the permeability constants: (a) correlation with the Darcian permeability constant $\left(k_{1}\right)$, (b) correlation with the non-Darcian permeability constant $\left(k_{2}\right)$.

[Figura 5: Correlação entre $R / m$ e as constantes de permeabilidade: (a) correlação com a constante de permeabilidade Darciana $\left(k_{1}\right)$, (b) correlação com a constante de permeabilidade não-Darciana $\left(k_{2}\right)$.]

structure and $k_{j}$ is the permeability constant, being $j=1$ or 2 for Darcian and Non-Darcian constants and $i=1$ or 2 for sample groups manufactured with smaller and larger grains, respectively.

The results obtained from the curve fittings demonstrate that for $j=1$ (Darcian case) the parameter $C_{1}^{(1)}\left(312,29 \times 10^{3}\right.$ $\mathrm{g}^{-1}$ ) is approximately two times greater than the parameter $C_{1}^{(2)}\left(158,94 \times 10^{3} \mathrm{~g}^{-1}\right)$. While the parameter $\alpha_{1}^{(1)}\left(2,32 \mathrm{~m}^{-2}\right)$ is practically identical to the parameter $\alpha_{1}^{(2)}\left(2,45 \mathrm{~m}^{-2}\right)$. For the case where $j=2$ (Non-Darcian case) the parameter $C_{2}{ }^{(1)}$ $\left(723,37 \mathrm{~g}^{-1}\right)$ is about five times greater than the parameter $C_{2}{ }^{(2)}\left(137,40 \mathrm{~g}^{-1}\right)$ and the parameter $\alpha_{2}^{(1)}\left(2,80 \mathrm{~m}^{-1}\right)$ is different to $\alpha_{2}^{(2)}\left(4,86 \mathrm{~m}^{-1}\right)$. As shown graphically and demonstrated here, the methodology is more sensible to non- Darcian phenomena. Even so, it still is possible to verify the influence of phenomena related to Darcian theory.

\section{CONCLUSIONS}

A novel application of the PA technique was used to investigate open-pore sintered glasses with high thickness (i.e. $4 \mathrm{~mm}$ ) and diffuse light beam transmission. This resulted in a new methodology for the determination of open-pore characteristics and permeability properties. The PA technique was able to provide information about the different structures of the sample groups and to relate them to the permeability constants. The results were not only demonstrated to be sensitive to the open porosity but also to the interaction between the open pore structure and the expansion of the interstitial air. New studies are necessary to complement this methodology and improve the agreement between the mechanisms involving the photoacoustic effect and the porous structure.

\section{ACKNOWLEDGEMENTS}

The authors are grateful to FAPESP, CNPq and Embrapa Research Center for their support of this work. The authors also thank Dr. Odílio B. G. Assis, Dr. Murilo D. M. Innocentini and Mr. Arturo R. F. Pardo for help in the discussion of results.

\section{REFERENCES}

[1] O. B. G. Assis, L. C. Claro, J. Non-Crystalline Sol. 247 (1999) 237.

[2] A. Rosencwaig, Photoacoustic and Photoacoustics Spectroscopy, John Wiley \& Sons, New York (1980) p. 309.

[3] A. Rosencwaig, Science 181, 4100 (1973) 657.

[4] T. H. Maugh, Science 188, 4183 (1975) 38.

[5] J. F. McCleland, R. N. Kniseley, Appl. Opt. 15, 11 (1976) 2658.

[6] A. C. Tam, Rev. Modern Phys. 58, 2 (1986) 381.

[7] W. L. B. Melo, R. M. Faria. Appl. Phys. Lett. 67, 26 (1995) 3892.

[8] A. Rosencwaig, A. J. Gersho, Appl. Phys. 47, 1 (1976) 64.

[9] F. A. Mcdonald, G. C. Wetsel Jr., J. Appl. Phys. 49, 4 (1978) 2313.

[10] M. T. Yasuda, MSc Thesis, Interunidades Eng. Ciência dos Materiais, USP, S. Carlos, SP (2003) p. 130.

[11] G. Rousset, F. Lepoutre, L. Bertrand, J. Appl. Phys. 54, 5 (1983) 2383. 
[12] J. P. Monchalin, L. Bertrand, G. Rousset, J. Appl. Phys. 56, 1 (1984) 190.

[13] S. J. McGovern, B. S. H. Royce, J. B. Benzier, J. Appl. Phys. 57, 5 (1985) 1710.

[14] F. B. Siebers, N. Greulich, W. Kiefer, Glastechnische Berichte 62, 2 (1989) 63.

[15] D. C. Vieira, Thesis, Interunidades Eng. Ciência dos
Materiais, USP, S. Carlos, SP (2002) p. 146.

[16] R. A. Vasques, M. D. M. Innocentini, O. B. G. Assis, Rev. Fís. Apl. Instrum. 14, 3 (1999) 1.

[17] M. D. M. Innocentini, V. R. Salvini, J. R. Coury, V. C. Pandolfelli, Am. Ceram. Soc. Bull. 78, 9 (1999) 78.

[18] M. D. M. Innocentini, V. C. Pandolfelli, Cerâmica 45 (1999) 61. 